\title{
FASCINATION WITH UNIFORM? \\ CHOOSING BETWEEN MILITARY AND CIVIL CAREERS IN THE EIGHTEENTH-CENTURY HABSBURG MONARCHY
}

\author{
OLGA KHAVANOVA \\ Institute of Slavic Studies of the Russian Academy of Sciences \\ austrian.centre.inslav@gmail.com \\ "Ad pedes Majestatis Vestrae Sacratissimae \\ humillima eaque homagiali devotione provolutus insto, \\ post praestita viginti annorum in omnibus retroactis bellicis \\ fidelia militaria servitia me in consiliarium Administrationis Scepusiensis \\ benigne resolvere dignetur"... \\ Josephus Baro Vécsey ${ }^{1}$
}

\begin{abstract}
The article deals with the phenomenon of popularity of military service in the eighteenth-century Habsburg Monarchy. It exemplarily examines cases of entering and quitting the army in a wider context of belated career-start or switch in profession. Most typical models under scrutiny are disillusioned officers losing hope of promotion, ex-Jesuits who had joined the army to compensate the consequences of the dissolution of the Society of Jesus, retired army officers using the patronage networks to get admitted to the administrative elites, and retired Hungarian guardsmen who had chosen administrative career. The study is based primarily on ego documents, such as petitions and private letters, which are supplemented (where available) by the minutes and resolutions of respective administrative bodies. Successful, or unsuccessful, case-studies under scrutiny let describing society of the Habsburg Monarchy as horizontally mobile and highly motivated to reach social ascend through flexibility in the occupations-choice.
\end{abstract}

Keywords: Habsburg Monarchy, military career, royal service, social mobility

\section{Introduction}

The eighteenth century brought the Habsburg dynasty a series of wars, which the Austrian historian Michael Hochedlinger has rightly called "the wars of emergence" [of the Austrian Monarchy"]. It might seem that the possibility to demonstrate courage on the battlefield and earn a higher rank or military order would 
have made the army career attractive for hundreds of ambitious youngsters. Yet, considering the composition of the Monarchy's officer corps, the historian came to the conclusion that "the Austrian-Bohemian nobility - with the exception of a few military dynasties often close to the Court - proved surprisingly reluctant to enter the officer corps, instead preferring posts in the more leisurely central and provincial administration." As a result, "the Austrian officer corps therefore remained as heterogeneous and cosmopolitan as ever."

This statistically verified statement based on the analysis of the Habsburg army personnel sounds persuasive. One should agree with the historian's assumption that the concept of the professionally trained officer provoked "aristocratic contempt" and consequently "have widened the gulf between traditional nobility and military service even more." By the same token, the practice of mass ennoblements of the officers of common origin - in the absence of other efficient, first of all financial mechanisms of encouragement of personal courage - "conserved or even reinforced the social openness of the officer corps." ${ }^{{ }^{3}}$ The Hungarian historian József Zachar came to a similar conclusion. Zachar calculated that in the period between 1693 and 1815 42,6\% of the Hungarian colonels in the Habsburg army came from the petty or landless nobility, and every fifth Hungarian general was of the common origin. ${ }^{4}$

Nonetheless the statement about the full indifference of the noble elites of the Monarchy to the career of an officer needs further specifications. Even random acquaintance with the history of aristocratic and lesser-noble families would rather lead to the assumption, that, as everywhere in Europe, ${ }^{5}$ children were more or less proportionately divided between the civil, military, and clerical careers, depending on their predispositions, physical conditions and progress in learning. And yet none of the child's (youngster's) inclinations were to bar his flexibility in catching up with as many career opportunities in his adult life as possible. As the rector of the Theresian College Theodor Kronstein warned Count Ferenc Nádasdy about his relative, the young Count Weichard Trauttmansdorf: "Before he joins one or another regiment, the count must finish his studies... insofar as we all know his inconsequent nature, there would be no wonder that the young man might change his mind to be an officer and, having no required preparation and knowledge for civil service, would be doomed to retreat to his estates, feeling little thankfulness for that."

In other words, the military service, once the young man decided to join the army, was never seen as his only career opportunity. In the age, when profession was in a way inherited from father to son (one might give numerous examples of military, or bureaucratic "dynasties"), there was a clear understanding, that one should use the opportunities suggested by the friendly circle, father's professional contacts, or the patronage networks available. Flexibility supported by good schooling and reinforced by useful acquaintances, was a sufficient foundation for a long, often diverse career. A young noble, as one shall see below, might start as 
an army officer and, getting retired in his thirties or forties, enter the civil service, or, begin as a clergyman and make up his mind to try his luck on the battlefield.

As to the military profession, interest in it in the Habsburg Monarchy obviously differed from one land to another. Thus, the Bohemian-Austrian nobility in the eighteenth century lacked the vast group of lesser, often landless nobles, who were indeed overrepresented in Hungary, including Croatia-Slavonia. In a country predestined to defend its southern borders from the Turks, sons of both aristocrats and impoverished nobles saw the military service as a profession, which matched their estates status or even promised quicker social ascend. The Hungarian historian Attila Réfi had analyzed the social and ethnic composition of the higher cavalry officers between 1792 and 1812 and came to the conclusion that this corpus was predominantly noble and Hungarian (not necessarily "Magyar" though). ${ }^{7}$ This might be extrapolated to the previous half century.

Hungarian graduates of the Viennese Theresianum are an instructive case to consider. This college was designed as a training-school for the future bureaucrats in different brunches and on different levels of power. A letter-writing manual composed especially for its pupils by the famous economist and jurist Johann Heinrich Gottlob Justi provides an indirect indication of this purpose. In 174955, Justi taught law and Cameralwissenschaften at the Theresianum. None of the sample-letters suggested that the graduates would apply for a position in the army. ${ }^{8}$ Yet two very first Hungarian pupils, admitted in 1746, József Niczky and Count András Berényi (1731-1816) - both sons of royal judges - became officers. In 1751, the empress ascribed the incomes of the rich southern-Hungarian abbey of St. Archangel Michael in Bátaszék to the Theresian College and ordered the nobles of the Austrian Monarchy to provide ten scholarships, of which at least half should come from the Kingdom of Hungary. Of the first five Bátaszék-pupils, two graduates had careers as royal servants, while three preferred to wear a uniform. ${ }^{9}$ As the Hungarian Noble Guard was founded in 1760 (to be considered below) many Hungarian pupils of the Theresian College - both the offspring of lesser noble families and illustrious magnates - tried join its ranks. Some of them, like Michael Bobok (1747-?), after two and a half years as guardsman (1766-69) went on with a military career in the standing army, others, like Count Zsigmond Zichy (1747-1803), after almost three years (1760-63) quit the Guard and later served at the Lieutenancy Council of the Kingdom of Hungary.

To get a more diversified picture of how young men were choosing between the military and civil service, or what were career-expectations among (retired) army-officers, and different layers of the nobility in general, on should also use sources, other than the regiments' documentation and similar statistics lead by the military authorities. Those could be first and foremost the archives of central governmental bodies of the Monarchy and private correspondence of the leading aristocrats of whom admissions and promotions in the army and bureaucracy 
might depend. In the former case, the most instructive might prove to be the Court Chamber with its wide network of affiliated offices responsible for collecting taxes, extracting salt or performing postal services. At the time, when a petition to the monarch combined the rigid epistolary norm with the most intimate overtones and was not determined in length and content, appeals to the sovereign contained precious pieces of information concerning both careers as expectations and possibilities. ${ }^{10}$ In the latter case, the epistolary collections of such Hungarian families, prominent both in the military and civil spheres as the Nádasdys or Károlyis provide a unique glimpse into the career strategies of the age. The Croatian Vice-Roy, proprietor of a cavalry regiment and commander-in-chief of the two confine regiments Count Ferenc Nádasdy (1708-83), or the high-sheriff of Szatmár county (most of its territory, including the administrative capital Satu Mare, is now in Romania), proprietor of an infantry regiment and Captain of the Hungarian Noble Guard Count Antal Károlyi (1732-91) helped more than one nobleman be enrolled into the army or win an administrative position.

Without intervening in the specific field of military history, extensive exploration of such groups of sources would necessarily enrich our knowledge of the age with an anthropological dimension, present impersonal lists of personnel as a sum of unique individuals with shared values, views and regularities in their behavior. This would also help verify the extent to which people were conceiving career as a foreseeable, rationally built sequence of actions, what were the factors, which made people more "professionally flexible," adjustable to the given circumstances and often limited opportunities on their way to power, wealth, prestige or simply a better lot. ${ }^{11}$

\section{Patronage}

Modern historiography no longer views patronage as corruption, i.e. the triumph of particularistic interests over the common good and nepotism, but rather considers it a composite part of early-modern state-building and nation-building. In a social order, where there were neither national-wide school system, nor its prerequisite - standard diplomas certifying knowledge and skills acquired, filling positions in the army and bureaucracy with apt individuals would have been impossible without omnipresent client's networks. ${ }^{12}$ The mechanisms of patronage in the early-modern Habsburg Monarchy might shed light on how noble youngsters became officers, and how retired officers were admitted to administration. The first dignitaries of the Monarchy were simultaneously filling positions at the court, holding key posts in the central royal and local county administration, possessing and commanding military units. This could not but attract numerous clienteles mainly the well-to-do county nobility, generations-long tied to their aristocratic 
patrons, who in exchange for their loyalty were employing their children in the subordinated offices or entrusted regiments. This widespread network was based on mutual trust, ${ }^{13}$ both between the patrons keeping each other informed about skilful men in their surrounding and between the patrons and their clients interested in the continuing advantageous cooperation through good offices.

The extent to which social ties outside the army penetrated into the military sphere is demonstrated by the following letter of Count Imre Esterházy to Count Antal Károlyi. Esterházy refused Károlyi’s friendly request to employ the young Baron Lepel as a cadet: "After the recent changes in the cavalry it became pretty obvious, that it would be merely impossible, to promote a youngster from such a good family, and even more so, inasmuch as along other cadets in my regiment there are sons of five county vice-sheriffs who serve by me, and with the reduction of one squadron none of them have any hope."14

Two letters to Count Ferenc Nádasdy written by a lesser nobleman from Vas/ Eisenburg County, a solicitous father Imre Bárdossy, ${ }^{15}$ give insight into the patronage mechanisms and its function in career-planning. His elder son József, after the personal intercession of the Hungarian Chancellor Count Lipót (Leopold) Nádasdy (1700-1758), received a royal scholarship to the Löwenburg noble college (Löwenburgisches Konvikt), where he spent 1756-1758. The young man's wish to join the army in the middle of the Seven Years War evoked ambiguous feelings in his parents. On the one hand, Ferenc Nádasdy's readiness to enroll the young man as an ensign and cover the necessary expenses was received with gratitude. On the other hand, given the Bárdossys' younger son had become a priest, they were concerned that had József fallen in the battlefield, this line of the family would die out. The father expressed hope that his son's military service would not last longer than one or two years, just to give him the necessary experience, and he prayed that the proprietor would not send the youngster into warfare, since the inexperienced ensign hardly understood Croatian.

The councilor of the Hungarian Court Chancellery József Kelcz had two sons, one of whom was a cadet in a military academy (most likely not in Wiener-Neustadt, but in Vienna) and dreamed about joining the standing army as soon as possible. The caring father had turned to their remote relative the influential courtier Count Ferenc Balassa with a request to intercede in enrolling the youngster in the Archduke Royal Lieutenant's Regiment, where should be a vacant place of a cadet. The father wrote: "My son is tall, of solid stature and is already educated in a way to become, of which I am sure, a useful citizen of the Fatherland." Already in a postscript he also added: "My abovementioned son speaks Latin, German, French and Hungarian languages." ${ }^{16}$ Balassa asked General Kempelen to be a mediator, and soon an assuring answer from Archduke Albert followed. Councilor Kelcz did not forget about his remote relatives and charges either and never missed an opportunity to remind regiments' proprietors about them. Thus 
in a letter to Antal Károlyi in 1778 he wrote: "Among others, since there are many occasions in these war circumstances, I supplicate: deign to take into consideration my humble relative Imre Novakovics, who has been serving, satisfactory, as I am informed, for some years in Your Excellence's regiment as a cadet." 17

Generally speaking, in a social order, where parental merits were building the starting point of the children's successful careers, it was by no means unusual, that the fathers (and mothers) were using the institute of patronage to render assistance to their apparently grown-up sons. In 1779, when the War for the Bavarian Succession was over, Count Ferenc Nádasdy’s minor client József Naypár was writing to his patron: "My poor son [László], whom Your Excellence could have long ago made a major, is still a corporal, and neither he, nor I in present peaceful times have a slightest hope of promotion." In the following lines he expressed his intention to turn to Prince Esterházy, asking him to admit the youngster to the Hungarian Noble Guard. Two years later, the persistent father was still besieging his patron with requests to take his son into consideration, lest a vacant place in the regiment were "given to others against the will of Your Excellence."18

By and large, patronage was omnipresent and indispensable in cases of both military and civil careers, as well as when one wanted to switch from one activity to another. The following examples of ex-members of the Society of Jesus, who decided to try their luck on the battlefield, show what a munificent patron might do for his protégé.

\section{Ex-Jesuits}

The careers of some ex-Jesuits give an indirect indication of the high prestige of the military service. The abolition of the Society in 1773 meant a great challenge for thousands of its members, both young and elderly. Those were ambitious youngsters, who had to feel in a way betrayed. They had joined the Society at seventeen or nineteen years of age, full of hope to reach higher positions in the rigid hierarchy, now in their mid-twenties they were to reconsider their career strategies. More than one decided to quit the clergy and become an official in central or local administration, or even to try his lot as an army officer.

So far, four instances of ex-Jesuit army officers have been found: the captain László Klobisiczky in the Károlyi Infantry Regiment, the ensign Karl Henseler and the second lieutenant Jakob Sussics in the 2nd Croat-Vice-Royal Confine-Regiment, and the cadet Johann Fischer in the Archduke of Toscana Carabineer Regiment. ${ }^{19}$ Yet, one also finds an interesting testimony in a letter of the auditor Sebastian Sprengl to Count Ferenc Nádasdy. He mentions an ex-Jesuit in uniform (whose name he did not notice), who was aspiring to be employed as a regiment-auditor or syndic and - in order to pass the prescribed examinations - was taking private 
lessons from the Vienna garrison-auditor in praxis militaris and attending lectures on criminal law at the university. ${ }^{20}$ Such cases, however rare they might be, let us better comprehend the phenomenon of a career as a symbolic investment of time, efforts and hopes and the place the army was taking in these speculations.

For example, the Hungarian nobleman László Klobusiczky (b. 1750) came from the family, which had been among devoted clients of the abovementioned Count Antal Károlyi. Antal Klobusiczky, László's elder brother, became, with his patron's protection, a minor clerk at the Hungarian Lieutenancy Council; his brother József - the future Fiume governor -finished his studies in the Waitzen (Vác) Theresian College at Count Károlyi's expense. László was 20 years old, when the Society of Jesus was dissolved. His elder brother György, also a Jesuit, preferred to become a priest was later appointed a canon to Nagyvárad (now Oradea Mare in Romania). László came to a decision to join the army. Antal Klobusiczky wrote to the family's patron Count Károlyi: "Brother László is now in Vienna and is waiting for an appointment, and Her Majesty expressed her ultimate satisfaction with his intention to join the infantry; she has also asked which regiment he would prefer and which of the regiment-proprietors he trusted most. On behalf of my brother the following answer came, that we due to God's providence grew up under the wing and patronage of Count Károlyi, and my brother would be very thankful indeed, if Her Majesty would ascribe him to the regiment of Your Excellence. It is most likely though (of what we should be informed soon), that the regiment of Your Excellence would be manned with one more cadet, hence, if the Bellicum issue were not arranged in some other way, I have the honour nunc pro tunc to entrust my poor brother to your fatherly solicitude and guidance of Your Excellence."21

Cadet Klobusiczky joined Károlyi's regiment on 1 September 1774, and in less than a year, on 1 August 1775, was promoted to ensign. His letters to the proprietor and patron were mainly written on occasions of his name days or New Year Eves, in an elegant Latin reminding of his former schooling and occupation and revealing less about his true hopes, fears or endeavors. ${ }^{22}$ The task of representing his younger brother's interests overtook Antal Klobusiczky, who was well informed about the daily routine of the infantry regiment: "For my brother's promotion in rank, which he thoroughly owes to the fatherly care of Your Excellence, we thank you from the bottom of our hearts, and inasmuch as we have recently learned, that the vacant charge of the recently died captain Ussovitz would be ascribed to one of the first lieutenants, I dare humbly recommend you my brother to the would-be-vacant charge of a first lieutenant." ${ }^{23}$ In three weeks affectedly surprised Antal Klobusiczky wrote to Károlyi again: "In as much as Your Excellence called my brother first lieutenant, I dare hope, that it happened due to kindness of Your Excellence and express my most devoted gratitude, unless it were a frivolity of your secretary." ${ }^{24}$ Ten years later, in 1789 , Klobusiczky was promoted to captain. He did not reach the rank of higher officer, but still had made a career others could envy. 
The opposite case presents the young Baron Carl Henseler (born in Brussels). After the dissolution of the Society, he was employed by Countess Patachich as a private tutor for her son Frederick studying in the Vienna Theresian Academy. An accidental acquaintance in her house with Count Ferenc Nádasdy, the Croat ViceRoy and commander-in-chief of two confine infantry regiments, changed the life of the twenty-three-year-old ex-Jesuit. He decided to try his fortune as an officer. Full of excitement, he wrote: "My only humble request to Your Excellence would be to confer me at least an officer title without wage... so that I could take part in military exercises or do them on my own, which is otherwise very uncomfortable in an abbé's dress." 25

It seems that the young ensign officer ${ }^{26}$ devoted all his ambitions and unspent zeal to his new vocation, as if he were trying to recompense "those nine years, which were consecrated to the service to the state in the Society of Jesus." $27 \mathrm{He}$ was permanently reminding his commander and benefactor: "I do not demand therefore to drive off my most well-earned comrades; my only desire goes as far as to be placed, in accordance with your disposal and will, in a stand, which would improve my condition just a bit." 28 Yet, as an unsuccessful latecomer Baron Hanseler had little chance of a quicker promotion. The fragmented state of the regiment's documentation for the late 1770s does not allow reconstructing his career after the War of Bavarian Succession (1778-79). Anyway, Baron Henseler remains an example of a fairly unlucky career switch from a clergyman to an army officer.

\section{Losing illusions}

For many young men their dreams of heroic deeds turned to be a wretched life in remote garrisons. They were suffering from the lack of money, were losing their vain hopes to be promoted from younger officers, or having been seriously wounded, were barred from any further participation in warfare. All these men sooner or later retired and searched for a new place in the bureaucracy at different levels. It might be suggested, that for many officers the military career was desirable until it justified its value and invested expectations.

The pupil of the Vienna Theresian Academy Count Maria Nepomuk Engelshaus (1753-1802) was introduced by his classmate Count József Draskovics to his stepfather - Count Ferenc Nádasdy. The elder son in an impoverished aristocratic family, Engelshaus had in the future the right of primogeniture on the family estates. Yet, as he calculated, the capital of thirty thousand invested at 4 or $5 \%$ interest rate would guarantee him twelve of fifteen hundred florins a year, of which he had to sustain his mother, two sisters and a younger brother. ${ }^{29}$ To serve in one of the confine regiments under the command of the Croat Vice-Roy Nádasdy seemingly opened perspectives which would have been brilliant for him. 
"What luck for a twenty-two-year-old young man, who, by the way, absolves his studies in July and has already made his utmost to become useful to his monarch and would do the same all his life long, - wrote Engelshaus, - when he has the luck to serve and obey under the glorious standards of the immortal - by his name and most honest deeds - field-marshal." ${ }^{30}$

The young man was taking his new vocation seriously: "I would like to thank Your Excellence as my benefactor for the advice concerning geodesy and the Croat language, for I have already made some progress: as to the former, it is mainly based on mathematics, as to the latter, hence I am a born Carniolean and speak my mother tongue pretty well." ${ }^{31}$ In a couple of weeks he assured his new patron: „I have good proficiency in accounting and have begun to acquire experience in calligraphy and judicial issues, inasmuch as I have been studying law for three years, Your Excellency might also rely on me." 32 The happy father, who, in an eloquent letter, thanked the regiment proprietor for his beneficence, presumed that his son would receive the rank of a lieutenant. ${ }^{33}$

Nevertheless the young man was enrolled just as an ensign ${ }^{34}$ and spent five years (1774-78) in a vain hope of promotion. In December 1777 he wrote: "I rely upon nobody but God and after God upon Your Excellence, I am confidant, that you have made many hundreds happy and just nobody unhappy, therefore I hope that Your Excellence would at first convenience embrace me with your kindness and let me be promoted to strengthen my zeal for service and provide me with better lot." ${ }^{35}$ Meanwhile Engelshaus got married, a child was born, and the deepest desperation moved the officer to address Nádasdy in the last (preserved) letter with the bitter words: "I want to find a civil office... and ask Your Excellence to let me quit, insofar as I would like as soon as possible to go from the regiment back home." ${ }^{36}$

Letters by young low officers to their regiment-proprietors might not be free from deliberate exaggeration and yet disclose their miserable existence. They fashion themselves as "poor abandoned cavaliers," enjoying monthly $3 \mathrm{fl}$. as cadets, or even no wage during their first years as ensigns, their impoverished aristocratic families failed to render them whatever aid, they were playing cards in vain hope to win money, or relying on occasional beneficiaries, as, for example, the ensign Count Joseph Stadl, who, according to his own confession, bought the uniform, horse and equipment at a bargain price from Count Erdödy. It took him ten years to be promoted from ensign to lieutenant. ${ }^{37}$ Others, less lucky, as Maria Nepomuk Engelshaus, preferred to quit the army.

\section{Having taken off the uniform}

Most likely, further traces of Maria Nepomuk Engelshaus' career could be found in Carniola. Was his switch from military to civil service typical? Inasmuch as 
historians do not have at their disposal prosopographic studies, devoted to the social composition of the bureaucratic elites of the Monarchy in the eighteenth century, it is hard to come to more general conclusions. Yet random references to the military service are found in petitions (both accepted and rejected), where retired officers, having served five, seven, ten, and more years in the army, commoners, nobles and aristocrats (see the motto chosen for this article) were requesting positions in central and local administration. A case typical for many is summed up in a petition of the officer-widow Katharina Pök: "My husband Ferdinand Pök having dedicated 28 years to the military service and seven years to the chamber service in the salt-office in Somlyó died in 1760." ${ }^{\prime 38}$

What were the preconditions of successful integration into the bureaucracy? Let us consider the case of the Chamber councilor Podivin von Kutschersfeld $(† 1769)$. This Bohemian nobleman joined the army around 1739, fought in the War of Austrian Succession, and in 1741 became a prisoner of war in Prague. After obtaining his freedom, he was assigned to the Savoy Dragoon Regiment in Italy, took part in numerous battles, and was wounded. He quit the military in 1752 at the rank of captain in order to fill the position of councilor in the Zips (in Hungarian called Szepes; now the region of Spiš in Slovakia) Chamber Administration situated in Kaschau (now Košice in Slovakia). Little is known about how this switch came about and who promoted the retired officer. In his later petitions, Kutschersfeld himself referred not once to his comprehensive experience in finances and administration: as an officer he had undertaken numerous private financial commissions for his military commanders. He was probably also a skilled financier and administrator given that the Vienna Court Chamber President, Count Rudolph Chotek, praised him as an "active, indefatigable and diligent man, who is competent in Hungarian fiscal issues, as well as in juridical and economic matters, [and] who has increased the income of the Hungarian crown estate of Altenburg [Óvár] such that last year the treasury received 30,000 fl. due to his skill. ${ }^{\prime 39}$ After ten years at the Court Chamber, Kutschersfeld was awarded a patent of Hungarian nobility. Even if his petition (1765) for the cross of the Order of St. Stephan was rejected, Podivin von Kutschersfeld's career at the Court Chamber may be considered exemplary in many ways.

Mathias Klohammer ( $\uparrow 1769)$ is another noteworthy example of the successful integration of a retired officer into the bureaucratic hierarchy. A commoner from Pressburg County (in Hungarian the town of Pressburg is called Pozsony; it is now Bratislava in Slovakia), he joined the county war effort in 1741 after the outbreak of the War of Austrian Succession, ${ }^{40}$ taking over the duties of a victuals- and quartermaster. The protection of the county's high-sheriff, Count János Pálffy, paved his way into the standing army. Cornet Klohammer served in Bavaria, Tirol and Northern Italy, was wounded (or, as he himself wrote: "I have been exposing my body and life to danger for the sake of serving my sovereign"), and after 14 years 
felt no longer up to military service. More than once, he requested that the empress employs him as a chamber official ${ }^{41}$ and pointed out his experience in accounting. In 1756, he received the position of salt-extractor in Körmend (Vas County) and a noble title. ${ }^{42}$ There is no direct indication that his transfer was arranged by the proprietor of his regiment, Count Ferenc Károlyi; on the other hand, someone probably persuaded the Chamber that the petitioner deserved this appointment. (Let us notice in brackets, that his elder son Johannes/János graduated from the Collegium Oeconomicum in Szenc/Wartberg (now Senec in Slovakia), was sent for nine months to study hydraulics in the Netherlands, later employed as a Court Chamber's hydraulic-engineer, and left behind a significant collection of books..$^{43}$ )

Early acquaintance with and practical experience in accounting and financial management obviously helped retired officers switch to a civil career. This circumstance made them employable in the whole range of chamber offices in central administrative bodies and in offices all over the kingdom. The retired officer János Sztankovics, who wanted to be employed by the Court Chamber as currier, wrote: "I have been serving for ten and a half years in the Archduke Ferdinand Infantry Regiment and during the last five years have been responsible for correspondence in Latin, Hungarian, German and Slovak and carrying financial matters; all officers including the regiment commissar were thoroughly satisfied with my work, what my retirement certificate and other credentials testify." ${ }^{4}$ Though in this particular case, it was the protégé of the Hungarian Court Chamber president who got the desired position, nevertheless the petitioner's belief in the relevance of his experience for the future appointment is remarkable.

Furthermore, the abovementioned instances demonstrate that both joining and quitting the army with a subsequent admission into the bureaucracy were hardly possible without influential patrons. Social practices of intercession were so widespread and in a way so transparent, that petitioners never hided the names of their beneficiaries. Captain Maximilian Rosenvals wrote in 1755 to the president of the Hungarian Chamber: "Having got the recommendation promised to med by Prince Liechtenstein, I pray Your Excellence about ultimate munificence and kindness: deign to take into consideration my 25 years of military service and merits I have seized, not less than lives of my father and six brothers dedicated to service in the army." The Hungarian Chamber immediately placed him the first among competitors to fill the vacancy of salt-extractor in the town of Baja in southern Hungary. ${ }^{45}$ In 1773, the minor clerk from a remote salt-office in Rhónaszék Johann Peter Bertin was a son and grandson of army officers, who was brought up in a military camp by a comrade of his deceased father. Yet the young man had to quit the army after being heavily wounded by a horse. As he would write almost half a century later: "In the end, having got a recommendation from General Count Zinzendorf I was admitted to the chamber service, which I have been performing already for 46 years." His eldest son was ascribed to assist 
him in the office, the second one became a hussar in Count Török's regiment, and for four minor boys the Chamber was to scholarships or other accommodation. ${ }^{46}$

It is hard to draw any general principle of personnel policy in regard of the retired officers. In every case the constellation of factors, such as the petitioner's ability to formulate a persuasive request, his luck with a patron and his ability to win the sovereign's compassion was different. Thus, Courier Lorenz Höbert from Rudolf Pálffy regiment failed to obtain the position of tax-collector in Pressburg despite his picturesque description of dangerous reconnaissance-missions in the Prussian rear during the Seven Years War. ${ }^{47}$ Yet Maria Theresa's endeavor both to give rational fundaments to philanthropy and to reserve enough space for the monarch's compassionate benevolence, could be traced in a whole number of voluntarily decisions on the cases with retired soldiers. For instance, the retired lieutenant Ludwig Donegg - a petty noble from the town of Szatmár (now Satu Mare in Romania) - persistently directed numerous petitions to the empress and the Court Chamber requesting employment as a tax-collector. Despite the fact that the Hungarian Court Chamber only ranked him third after two other candidates who were professional chamber-officials with the necessary professional experience, and the fact that the Vienna Court Chamber preferred another soldier, whose father had held this office before his death, the empress inexplicably tapped Donegg for the job "if he brings good testimony from his regiment" (which he did). ${ }^{48}$

It is remarkable that retired officers - unlike sons of the imperial-royal servants, who were almost predestined to run the same bureaucratic career often in the same little town, marketplace, or tax collector's office - enriched the bureaucratic corpora of the kingdom through ethnic diversity. Many of them were Hungari, that is ethnically non-Magyar subjects, or even members of the noble communities from other Habsburg provinces. In their new offices they had also successfully applied their personal and professional experience brought from abroad. For instance, Andreas Franz Puecher was a commoner from Sopron/Ödenburg County, who in 1728-1735 served in the Messina garrison in Sicily (in charge of the regiment's finances and logistics); later moved with Prince Lobkowitz's Regiment to the Apennine peninsula; once accompanied Austrian emissaries to the Ottoman Porte; and in the War for Austrian Succession was employed by Duke Carl of Lorraine as manager of his military finances. ${ }^{49}$ Such people were eroding the exclusivist character of the bureaucratic elite. In the nineteenth century, this social group would become one of the centripetal forces keeping the Monarchy together. ${ }^{50}$

Like any "outsiders" in the bureaucratic milieu, retired army-officers posed a potential threat to the basic principle of promotion in rank - gradual ascend in the bureaucratic hierarchy. In the system, where minor clerks were tediously waiting for the next appointment, employment of ex-officers came into contradiction with the proclaimed bureaucratic ethic. Such breaks in continuity were explicitly considered a danger to the existing order, which might cause undesired dissat- 
isfaction among the personnel. For example, in 1775 György Nászvady applied for a position in the Hungarian Court Chamber and wrote that he had dedicated thirteen years to the military service, got retired physically ruined and retired in the rank of captain. Feeling himself still in good condition for the civil service, he was ready to convert his military pension into salary "in order not to pose burden for the royal treasury." The head of a numerous family, obliged to educate his children, he was at the edge of financial ravage, because one half of the modest fortune inherited from his mother was bonded for debts. The royal service seemed to Nászvady a way to improve his financial lot and continue being useful for the public good. On the empress' request the president of the Chamber Count Festetics answered though, that despite the petitioner possessed the required skill to serve in this governmental body, the Chamber cannot suggest him any position comparable with his actual pension (there was the whole number of minor clerks "standing in the line" for such an appointment). For this reason, as a usual form of polite refuse, it was ordered to keep an eye on Nászvady, but even in the best case he would not have gotten a wage higher than $200 \mathrm{fl}$. a year. ${ }^{51}$

The monarch as the ultimate patron and beneficiary of the subjects was often practicing his/her absolute right to make final decision on the appointments to promote retired officers incapable of military service. In the age of permanent wars, dozens of disabled young men were accommodated due to Maria Theresa's motherly compassion reinforced by her sense of sovereign's responsibility for the subjects. On the other hand, the practice of employing amateurs in financial matters was less and less welcomed by the Chamber authorities. When Maria Theresa asked through her cabinet-secretary to employ a sergeant from Esterházy Regiment as salt-office controller in Pécs/Fünfkirchen, the Court Chamber advised the empress to find a another job for this "highly experienced in surgery and deserving consolation in his own sphere" man..$^{52}$

\section{The Hungarian Noble Guard}

This Hungarian Noble Guard ${ }^{53}$ was created in 1760 to socialize provincial nobles at court, picking up the most gifted and ambitious for further promotions in the army and administration, "re-delegating" them to the estate structures, and so forth. Insofar as the selection of the candidates was in the competence of the Hungarian counties, most of the guardsmen came from the old provincial nobility, often sons of the dignitaries in the county administration. Young men - sometimes after years of military service, but more frequently just after finishing their education, be it a noble college or university - spent four, seven and even more years in Vienna and then were allowed to choose between the military and civil career. Hungarian guardsmen could be described as an exact example of "spon- 
sored mobility" ${ }^{\prime 4}$. (The term was introduced by the American sociologist Ralf Turner, who argued that coherent elites and their agents controlled the induction of new recruits into its ranks by selecting them at an early age and requiring them to meet its standards). In the case of the Noble Guard, personal acquaintance with the empress ${ }^{55}$ and proximity to the decision-making centers made further accommodation of guardsmen incomparably easier.

Indeed, many former guardsmen who had chosen a civic career could be found in the Court Chamber, or its tax and salt, and post offices, Hungarian Court Chancellery, and Royal Lieutenancy Council, in district courts of justice, county- and town-administrations. The share can be calculated from the biographic lexicon of the Hungarian historian Kálmán Hellebronth ${ }^{56}$ and totals approximately one third. Archives of the central governmental bodies of the Monarchy as well as private correspondence of the prominent aristocrats preserve guardsmen's petitions and private letters, as well as the official papers with considerations, decisions and resolutions made on particular instances. These sources unveil reasons and circumstances, why guardsmen were striving, - successfully, or in vain, - to get employment as royal servants, and which arguments they adduced in their favor.

For the guardsmen, there were apparently three career opportunities: to quit and be given a position in administrative or judicial sphere, to go on with their "paramilitary" service at court and keep on fruitlessly applying to civil jobs to get retired with a modest pension. For example, the young noble from Abaúj County Michael Cserghö (1738-?), whose father (the county notary) died, when the boy was just three years old, got educated and was employed by the county administration as a minor clerk. In the age of twenty-one he was enrolled, among the very first ones, as a Hungarian guardsman and spent eleven years (176071) in the Habsburg capital. His skills in letter-writing and clever self-fashioning helped him, without any doubts, to win the empress' benevolence. "I did not waist a single hour, - wrote Cserghö in an eloquent petition, - but have used the time free from my routine duties for learning the natural law and the law of nations, the Cameral-Wissenschaften in accordance with Sonnenfels' principles of accounting, and, the last but not the least, made progress in the German and Italian languages, and all that with the passionate zeal to be even more useful to Your Majesty." ${ }^{57} \mathrm{He}$ was eventually employed at the Hungarian Court Chamber in 1771, soon promoted to the vice-secretaries, and in 1776 became a secretary, where he remained until 1783.

In contrast, Jozsef Doczy (1741-1825) from Zala County joined the Noble Guard in 1762, served in Pressbug, Parma and Milano, accompanied Joseph II on the War of Bavarian Succession, he was making his sure progress in rank and got retired in 1819 as colonel. His petitions about employing him as an out-of-stuff assessor in the administration subordinated to the Hungarian Chamber, remained just an episode in the officer career. Yet he was well informed about the vacancies 
and, similar to his comrades, that during "the time that I spent in Milano, I was not only most punctually fulfilling my duties, but also studying sciences and languages, in order to be capable of filling such an office." ${ }^{58}$ His fellow-guardsman Imre Györgyi (1741-?) more than once asked to employ him at the Hungarian Court Chamber, but failed to persuade the authorities, and, as the president of this governmental body advised the empress, "the request of the supplicant could be recommended even less, inasmuch one can easily presume that he possesses no required knowledge of or familiarity with the responsibilities of a Chamber assessor." ${ }^{59}$ Which role did the patronage of influential aristocrats play in cases of positive, or negative decisions, one could reconstruct from private correspondence. For example, in 1783 Count Károly Zichy recommended to the President of the Hungarian Chamber Count Ferenc Balassa the ex-officer and actual guardsman Pál Zsitkovszky (1753-?) to the office of salt-collector in Pressburg. ${ }^{60}$ That time this private request was not satisfied, but in one or another way the officer was retired in 1785 and soon was employed as postmaster in the town of Tokai.

Although it was presumed that, after years spent in Vienna, the guardsmen were fluent in German, the personal files of those who were employed as royal servants reveal details showing that this assumption is flawed. For example, Elek Okolicsányi (1744-?), the offspring of an old and merited noble family, having served in the standing army, joined the Hungarian Guard in 1763 and after six and a half years quitted as lieutenant. In 1773, he applied for a job in the Zips Chamber Administration. The authorities have found the way to satisfy his request: Okolicsányi's pension was converted into his salary. As any applicant, he was supposed to take a routine examination in German and prove his aptness for a chamber-office, but his chief Count József Török gave him (although in a semi-private writing) an uncomplimentary assessment: "Okolicsányi makes an impression, that he does not understand German at all, and even less is able to work using this language, his analytical capacity is modest, his temper is troubled, he is inclined to intrigues." 61

Okolicsányi's numerous petitions preserved in the Court Chamber archives prove Török's assumption. The public discourse of the age implied that the subjects had their full right to request remuneration from the sovereign for troubles, losses and inconveniences suffered for the sake of the public good. One can find the whole spectrum of the most common topoi there: conversion to Catholicism, which deprived him of aid and support of his Protestant relatives and friends, unbearable costs of a privately undertaken trip to Pressburg in order to win the empress' audience and supply for a higher position, humiliation felt by a retired lieutenant doomed to live miserable life of a badly-paid minor clerk and so forth. Yet it seems the authorities did not consider him worthy of promotion: in 1779 his petition for appointment as a chamber-administrator to Zombor was rejected, ${ }^{62}$ and the ex-guardsman went on with his work in Kaschau. 


\section{Some conclusions}

Destinies of both Hungarian guardsmen and standing-army officers testify that individuals in the eighteenth century were perfectly aware of career as social rise, which resulted from symbolic investment of time and skills and clever exploitation of available social ties. The Habsburg army was, as ever, awakening expectations of quicker ascend and, for this reason, attracted youngsters of both noble and non-noble origin. By the same token, dangers and inconveniences of military profession coupled with the impossibility of making a spectacular career within a short period of time was pushing young and ambitious men to quit the army and try their lot in the bureaucracies. Furthermore, retired officers in their forties and fifties still felt themselves capable of serving the public good, and the civil career became for them a decent way of sustaining their families, giving their children a better start in the adult life. Eighteenth-century individuals, coping with circumstances, were demonstrating a high degree of flexibility in adjusting to the situation, when they were to change their chosen vocation. Society of the Habsburg monarchy considered through the prism of men choosing between the arguments "pro" and "contra" a career in the army, could be described as a social order with a relatively high degree of horizontal (and to a certain degree vertical) mobility.

\section{Notes}

1 "Prostrated to the feet of Your Most Sacred Majesty, I pray with humble and true devotion: deign to appoint me, after twenty years of my in all recent wars loyally exposed military services, to the post of a councilor at the Chamber Administration to Zips." See: Österreichisches Staatsarchiv, Wien (hereinafter ÖStA), Finanz- und Hofkammerarchiv (hereinafter FHKA), Hoffinanz Ungarn (hereinafter HFU), Fasz. r. Nr. 834, 24. Apr. 1752, fol. 318r.

2 Michael Hochedlinger, Austria's Wars of Emergence: War, State and Society in the Habsburg Monarchy, 1683-1797 (London-New York 2003) 305.

3 Michael Hochedlinger, "Mars Ennobled. The Ascent of the Military and the Creation of a Military Nobility in Mid-Eighteenth-Century Austria," in German History 17/2 (1999) 141-76.

4 József Zachar, “A katonai pálya mint karrierlehetőség a XVIII. századi Magyarország előtt. Történeti-statisztikai adalék a társadalmi mobilitás kérdéséhez,” in: Írott és tárgyi emlékek kutatója. Emlékkönyv Bánkúti Imre 75. születésnapjára, ed. K. Mészárós (Budapest 2002) 249-59.

5 Marc Motley, Becoming a French Aristocrat: The Education of the Court Nobility 1580-1715 (Princeton, 1990); cf.: Karin Jutta MacHardy, "Cultural Capital, Family Strategies and Noble Identity in Early Modern Habsburg Austria, 1579-1620," in: Past and Present 163 (1999) 36-75.

6 Magyar Országos Levéltár, Budapest [Hungarian National Archives, hereinafter MOL] P 398, Nádasdy család. B. X. Nádasdy Ferenc horvát bánhoz címzett levelek, 35. cs., no. 433, Theodor Kronstein to Ferenc Nádasdy, sine dato [1772?].

7 Attila Réfi, “A császári-királyi huszárezredek törzstisztikara a francia háborók időszakában (1792-1815),” in: Századok, 142/5 (2008) 1267-90.

8 Johann Heinrich Gottlob von Justi, Anweisung zu einer guten Deutschen Schreibart und allen in den Geschäfften und Rechtsachen vorfallenden schriftlichen Ausarbeitungen zu welchen Ende allenthalben wohlausgearbeitete Proben und Beyspiele beygefüget werden (Wien 1774) 213. 
9 The list of the Theresianum graduates see: Max Fraiherr von Gemmell-Flischbach, Album der k. k. Theresianischen Akademie (1746-1913). Verzeichnis sämtlicher Angehörigen der $k$. $k$. Theresianischen Akademie (ehemals $k$. $k$. Theresianische Ritterakademie) ... mit kurzen biographischen Daten (Wien 1913) 19-62. For the detailed analysis of the functioning of the Bátaszék fund cf.: Olga Khavanova, Zaslugi otsov i talanty synovei: vengerskie dvoriane v uchebnykh zavedeniiakh monarkhii Gabsburgov [Fathers' merits and sons' talents: Hungarian nobles in schools of the Habsburg Monarchy] (St Petersburg 2006).

10 Cf.: Olga Khavanova, A kérelemírás mestersége és hivatalnoki pályafutások a XVIII. századi Habsburg Monarchiában [The Art of Writing Petitions and Bureaucratic Careeres in the Eighteenth-Century Habsburg Monarchy], in: Századok 142/5 (2008) 1249-66.

11 See more: Olga Khavanova, Userdie, chestolyubie i kariera: chinovnichestvo v monarkhii Gabsburgov v epokhu prosveshchennogo absolutizma [Diligence, ambition and career: administrative elites in the later eighteenth-century Habsburg Monarchy] (Moscow 2018).

12 Heiko Droste, "Patronage in der Frühen Neuzeit - Institution und Kulturform," in: Zeitschrift für Historische Forschung, 30 (2003) 555-590.

13 It is noteworthy that another widespread network of the early modern period, the republic of letters, was organized in many ways along the same lines. Cf.: Franz Mauelshagen, "Netzwerke des Vertrauens. Gelehrten Korrespondenzen und wissenschaftlichen Austausch in der Frühen Neuzeit," in Vertrauen. Historische Annäherungen, ed. Ute Frevert (Göttingen, 2003) 119-51.

14 MOL P 398, Károlyi család levéltára, Missiles [The Károlyi family archive, Correspondence (hereinafter P 398)], no. 16734, Imre Esterházy to Antal Károlyi, 14 June 1771.

15 MOL P 507, 25. cs., no. 143, Imre Bárdossy to Ferenc Nádasdy, 8 March 1758; 18 May 1758.

16 MOL P 1765, Balassa Ferenc levéltára [Ferenc Balassa's archive], 65. cs., 22. t., no. 4494, József Kelcz to Ferenc Balassa, 6 October 1777.

17 MOL P 398, no.38163, József Kelcz to Antal Károlyi, 19 March 1778.

18 MOL P 507, 36. cs., no. 515, József Naypár to Ferenc Nádasdy, 23 November 1779; 6 February 1781.

19 The last was, for example, enrolled not as a Jesuit, but as a student, although his father's petition to the monarch describes him as a former member of the Society of Jesus. Cf.: ÖStA, FHKA, Österreichisches Camerale, Fasz. 10, Fasz. r. Nr. 663, "F.V.U.," 50 ex Mar. 1774, Fol. 93.

20 MOL P 507, 41. cs., no: 683, Sebastain Sprengl to Ferenc Nádasdy, 17 June 1774.

21 MOL P 398, no. 40069, Antal Klobusiczky to Antal Károlyi, 9 July 1774.

22 Cf.: MOL P 398, nos. 40462-82, László Klobusiczky to Antal Károlyi, 18 March 1775 - 17 December 1790.

23 MOL P 398, no. 40080, Antal Klobusiczky to Antal Károlyi, 3 March 1779.

24 MOL P 398, no. 40069, Antal Klobusiczky to Antal Károlyi, 23 March 1779.

25 MOL P 507. 33. cs., no. 347, Karl Henseler to Ferenc Nádasdy, 29 October 1774.

26 ÖStA, Kriegsarchiv (hereinafter KA), Musterlisten (hereinafer ML). Kt. 5923 (2do Banal-Infanterie Regiment).

27 MOL P 507, 33 cs., no. 347, Karl Henseler to Ferenc Nádasdy, 1 November 1778.

28 MOL P 507, 33 cs., no. 347, Karl Henseler to Ferenc Nádasdy, 10 November 1776.

29 MOL P 507, 30. cs., no. 255, Maria Nepomuk Engelshaus to Ferenc Nádasdy, 1 October 1776.

30 MOL P 507, 30. cs., no. 255, Maria Nepomuk Engelshaus to Ferenc Nádasdy, 22 December 1773.

31 MOL P 507, 30. cs., no. 255, Maria Nepomuk Engelshaus to Ferenc Nádasdy, 11 January 1774

32 MOL P 507, 30. cs., no. 255, Maria Nepomuk Engelshaus to Ferenc Nádasdy, 25 January 1774.

33 MOL P 507, 30. cs., no. 255, Maria Ignaz Engelshaus to Ferenc Nádasdy, 25 January 1774.

34 Maria Nepomuk Engelshaus' name is mentioned in the Indices of the Court Military Council (Hofkriegsrat), but the acts do not exist anymore. See: ÖStA. KA. Hofkriegsrat. Index (pub- 
licis). Bd. 1101; 1113. The random acts of the banal regiments are dramatically incomplete exactly for the years $1774-1778$.

35 MOL P 507, 30. cs., no. 255, Maria Nepomuk Engelshaus to Ferenc Nádasdy, 15 December 1777.

36 MOL P 507, 30. cs., no. 255, Maria Nepomuk Engelshaus to Ferenc Nádasdy, 2 Fenruary 1778.

37 Letters of Count (according to Constant Wurzbach - Baron) Josef Stadl to Ferenc Nadasdy see: MOL P 507, 41. cs., no. 684.

38 ÖStA, FHKA, Camerale Ungarn (hereinafrer CU), Fasz. 29, Fasz. r. Nr. 604, Subd. 1, no. 24 ex Aug. 1764.

39 ÖStA, FHKA, Hoffinanz Ungarn (hereinafter HFU), Fasz. r. Nr. 917. 15. Jan. 1762, fol, 442r.

40 More than one young royal official in the early 1740s joined the noble insurrection in the hopes of trying his lot as a soldier. For example, the young chamber official Ignáz Kákony, having served three years in Pressburg, joined the insurrection in 1741 and quitted military service three years later in order to go on with the chamber service (where his father was also employed). Cf.: ÖStA, FHKA, HFU, Fasz. r. Nr. 831, 31. Oct.1751, fol. 545-50.

41 Cf.: ÖStA, FHKA, HFU, Fasz. r. Nr. 857, 2. Sept. 1755, fol. 24-26; Fasz. r. Nr. 864, 4. Maj. 1756, fol. 169-70.

42 MOL A 57, Királyi Kancellária Levéltára, Libri Regii, 44. köt., pp. 296-8.

43 See: Hegyi Ferenc, "Klohammer János XVIII-XIX. századi geometra-hidraula könyvtára" [The library of the eighteenth-nineteenth-century geometrician and hydraulics engineer János Klohamer], in: Magyar Könyvszemle, 96/1 (1980) 60-9.

44 MOL, Magyar Udvari Kamara Levéltára [The archives of the Hungarian Court Chamber], Cancellariae et registraturae ... negotia (hereinafter E 47), 19. cs., no. 599 ex Sept. 1775.

45 ÖStA, FHKA, HFU, Fasz. r. Nr. 853, 11 Mar. 1755, fol. 94-5.

46 ÖStA, FHKA, UC, Fasz. 19, Fasz. r. Nr. 423, no. 82 ex Dec. 1773, fol. 468-76.

47 ÖStA, FHKA, HFU, Fasz. 899, 3 Jul. 1760, fol. 271r.

48 ÖStA, FHKA, HFU, Fasz. r. Nr. 818, 16 Maj. 1749, fol. 163-89.

49 ÖStA, FHKA, HFU. Fasz. r. Nr. 789, 5. Dec. 1744, fol. 233r.

50 István Deák, Beyond Nationalism: A Social and Political History of the Habsburg officer Corps, 1848-1918 (New York-Oxford, 1990).

51 MOL, E 47, 19. cs., no. 133 ex Dec. 1775.

52 ÖStA, FHKA, HFU, Fasz. r. Nr. 869, 18 Apr. 1757, fol. 143r, 147r-v.

53 Illéssy János, “A magyar királyi nemes testőrség felállítása 1760-ban” [The foundation of the Hungarian Noble Guard in 1760], in: Hadtörténeti Közlemények, 8 (1895) 367-94.

54 See: Ralf H. Turner, "Sponsored and contested mobility" in: American Sociological Review, 25/6 (1960), pp. 856-7.

55 For instance, the guardsman Antal Paxi wrote in his petition: "Your Most Sacred Majesty, on the occasion of a kindly given audience, to my humble request ... to be attached to an aged salt-inspector, honoured me with the gracious answer that I was to describe my case in a supplication that would be considered in a due course by the Hungarian Court Chamber." See: ÖStA, FHKA, UC, Fasz. r. Nr. 423, no. 3 ex Sept. 1773, fol. 139v.

56 Hellebronth Kálmán, A magyar testörségek névkönyve, 1760-1918 (Budapest, 1940).

57 ÖStA, FHKA, UC, Fasz. 1, Fasz. r. Nr. 4, Konv. 2, no. 63 ex Aug. 1771, fol. 61.

58 MOL, E 47, 20. cs., no. 190 ex Mar. 1776.

59 ÖStA, FHKA, UC, Fasz. 29, Fasz. r. Nr. 592, Subd. 1, no. 1 ex Jun. 1776, fol. 168r.

60 MOL, Balassa család levéltára, P 1765, Balassa Ferenc levéltára, 86. cs., 22. t., no. 9762 , Károly Zichy to Ferenc Balassa, 11 October 1783.

61 ÖStA, FHKA, UC, Fasz. 27, Fasz. r. Nr. 591, Subd. 1, no. 49 ex Jul. 1774, fol. 459v.

62 ÖStA, FHKA, UC, Fasz. 27, Fasz. r. Nr. 592, Subd. 1, no. 122 ex Jul. 1779, fol. 241, 244-5r. 